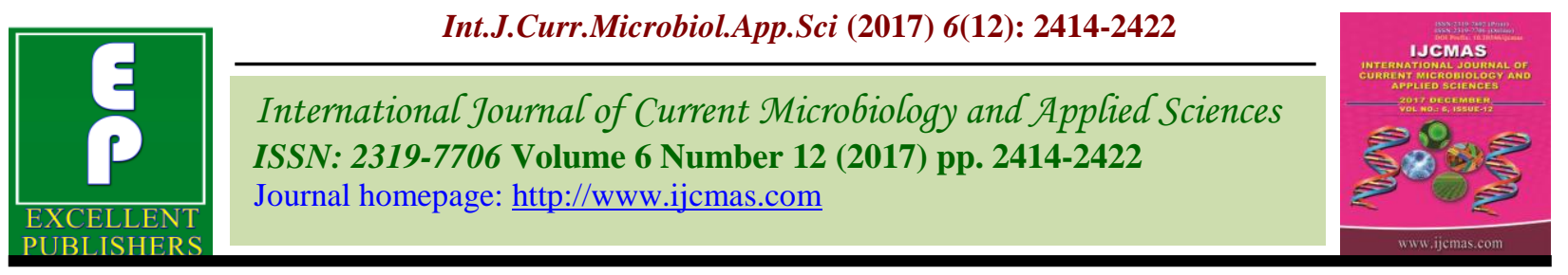

Original Research Article

https://doi.org/10.20546/ijcmas.2017.612.279

\title{
Centurial Rainfall Variability in Below Sea Level Farming Region of Kerala, India
}

\author{
P. Shajeesh Jan", S. Paneerselvam, V. Geethalakshmi, K.P. Ragunath, \\ Ga. Dheebakaran and R. Jagannathan
}

Agro Climate Research Centre, Tamil Nadu Agricultural University, Coimbatore, Tamil Nadu, India

*Corresponding author

\begin{tabular}{|c|c|}
\hline & A B S T R A C T \\
\hline & An investigation was made to study the temporal variation in monthly, seasonal \\
\hline $\begin{array}{l}\text { Ke y w o r d s } \\
\text { Rainfall variability, } \\
\text { Mann - Kendall rank } \\
\text { statistics and trend } \\
\text { analysis. }\end{array}$ & $\begin{array}{l}\text { and annual rainfall over Kuttanad region, a unique region of India, where farming } \\
\text { is practiced below sea level conditions. The region is also signifies the rice bowl } \\
\text { of the Kerala state. The long term changes in rainfall during the period from 1901- } \\
2015 \text { was determined by Mann - Kendall rank statistics for the trend analysis and } \\
\text { linear trend. The variation in annual and seasonal rainfall were also investigated }\end{array}$ \\
\hline Article Info & but was not statistically significant. The study revealed that rainfall during \\
\hline $\begin{array}{l}\text { Accepted: } \\
17 \text { October } 2017 \\
\text { Available Online: } \\
10 \text { December } 2017\end{array}$ & $\begin{array}{l}\text { trend in April and September. The increasing rainfall during peak summer period } \\
\text { of April favours plantation crop and lowland spice crop and increased rainfall } \\
\text { during September was benefit to the Winter rice crop which is the major rice } \\
\text { growing season of this region. }\end{array}$ \\
\hline
\end{tabular}

\section{Introduction}

Climatic variability and extremes constitute a major challenge to reliable crop productivity, farmers' incomes and hence food security (Gourdji et al., (2013); Knox et al., (2012); Lobell et al., (2008), Brown and Funk (2008); Battisti and Naylor, (2009). Pramanik and Jagannathan (1954), Parthasarathy and Dhar (1978), Parthasarathy (1984), Mooley and Parthasarathy (1983), Parthasarathy et al., (1993) analysed detailed long-term trends of Indian monsoon rainfall for the country as well as for small sub divisional basis. Rupa Kumar et al., (1992) analysed monsoon rainfall variability across Indian region for the past 100 years and showed that, in Northeast peninsula, Northeast India and Northwest peninsula experienced a decreasing trend in monsoon rainfall whereas in the west coast, central peninsula and Northwest India experienced increasing trend. Singh et al., (2005) observed that annual rainfall over major basins in Central India (Sabarmati, Mahi, Narmada, Tapi, Godavari and Mahanadi) showed decreasing trend since the 1960s, whereas Indus, Ganga, Brahmaputra, Krishna and Cauvery basins showed an increasing trend. Guhathakurta and Rajeevan (2007) observed decreasing trend of rainfall 
in almost all subdivisions except for subdivisions in Himachal Pradesh, Jharkhand and Nagaland, Manipur, Mizoram and Tripura during winter season. The above study also revealed that, pre-monsoon season rainfall over most parts of the Central India, Gujarat region, West Madhya Pradesh, East Madhya Pradesh, Vidarbha, Chattisgrath and Jharkhand and in the case Chattisgrah, Jharkhand and Kerala, annual and Southwest monsoon rainfall showed significant decreasing trend. Temporal variation in monthly, seasonal and annual rainfall over Kerala, during the period from 1871 to 2005 were analysed by Krishnakumar et al., (2009) and the results inferred that rainfall during winter and summer seasons showed insignificant increasing trend where as rainfall during June and July showed significant decreasing trend while increasing trend was noticed during January, February and April months.

\section{Materials and Methods}

\section{Location}

Kuttanad region comprises of ten taluks spread over the three districts viz., Alappuzha, Kottayam and Pathanamthitta of Kerala state (Fig. 1). More than two third of the total land area in this region is wetlands. Enriched by the silt deposited through the river systems of Meenachil, Pamba, Manimala and Achencoil and suitable for rice cultivation.

The historic climate data for the study period was extracted from Climate Research Unit time series data (CRU TS). CRU TS contained monthly time series of precipitation covering earth's land areas for 1901-2015.In this study, recent release CRU TS4.0 was used. The data set is gridded to $0.5 \mathrm{x} 0.5$ degree resolution, based on analysis of over 4000 individual weather station records. The CRU data in Net CDF files format were extracted and the grid points near to the grid points of the study area were identified and taken for analysis. There were eight grid points pertaining to Kuttanad region

The CRU gridded data were validated with the observed rainfall data (1991-2014) obtained from twelve rain gauge stations of India Meteorological Department (IMD) are depicted in Table 1.

\section{Results and Discussion}

From the rainfall data,monthly mean, seasonal rainfall, Standard Deviation (SD) and Coefficient of Variation (C.V.) were computed monthly and season-wise viz., summer (March-May), Southwest monsoon (June-September), Post-monsoon (OctoberNovember) and Winter (December-February) that are depicted in Table 2.

To support trends in annual and seasonal rainfall, decade-wise shifts in rainfall over Kuttanad region were also analysed from the period 1901 to 2015. Temporal changes in the seasonal and annual rainfall were also analysed by Mann-Kendall rank statistics to confirm the significance of the observed trend.

\section{Rainfall features}

Rainfall behaviour of Kuttanad region are reported in Table 2. The annual normal rainfall over Kuttanad region from 1901 to 2015 is $2594 \mathrm{~mm}$ with a standard deviation of $315 \mathrm{~mm}$. The coefficient of variation of annual rainfall is $12.1 \%$, indicating that it is highly stable. Rainfall during July is the highest $(488.4 \mathrm{~mm})$ and contributes to $18.8 \%$ of annual rainfall $(2594 \mathrm{~mm})$, followed by June (18.5\%). Rainfall in August and September contributes to $12.5 \%$ and $9.7 \%$ of the annual rainfall, respectively. Rainfall in January was the least $(16.3 \mathrm{~mm})$ and 
contributes only $0.6 \%$ to the annual rainfall. The coefficient of variation is also the highest during January (104.5\%), followed by February (101.6\%) and December (81.8\%) and the least during the high rainfall months of July (26.2\%) and June (31.4\%). Rainfall during the southwest monsoon (JuneSeptember) contributes $59.5 \%$ of the annual rainfall.

The percentage contribution of post-monsoon (October- November), summer rainfall (March-May), and winter rainfall (DecemberFebruary) to the annual is 20.0, 16.8 and 3.7 respectively. The seasonal rainfall during monsoon (June-September) is dependable as the coefficient of variation is $18.1 \%$. At the same time, rainfall during winter is undependable as the coefficient of variation is very high $(51.2 \%)$, varying between $81.8 \%$ in December and $104.5 \%$ in January.

\section{Rainfall trends}

\section{Annual rainfall trends}

The mean annual rainfall over Kuttanad region showed a long term insignificant declining trend (Fig. 2). A decrease of 64.63 $\mathrm{mm}$ only was noticed during the study period of 115 years as against the normal rainfall of $2594 \mathrm{~mm}$.

\section{Seasonal rainfall trends (Figure 3)}

\section{Summer rainfall (March- May)}

There was an overall insignificant increase during the study period of 115 years. An increase of $24.8 \mathrm{~mm}$ was noticed as against the normal $(436.3 \mathrm{~mm})$.

\section{Southwest monsoon (June-September)}

The Mann- Kendall test statistics (-0.764) indicates that the there was insignificant decrease in southwest monsoon rainfall. Overall, a decline of $72.12 \mathrm{~mm}$ was noticed during the study period of 115 .

\section{Post-monsoon (October-November)}

The Mann-Kendall test indicated that the seasonal rainfall during the post-monsoon showed insignificant decrease significant. It also showed through the trend line that the decrease was only $2.46 \mathrm{~mm}$ during the study period of 115 years.

\section{Winter (December-February)}

The winter rainfall had a decreasing tendency, which is not statistically significant. It also showed through the trend line that a decrease of $19.9 \mathrm{~mm}$ only was noticed during the study period of 115 years.

\section{Monthly rainfall trends}

Monthly rainfall behaviour of Kuttanad region has been studied for individual months by subjecting them to the Mann-Kendall test. The results are presented in Table 3. It is interesting to note that rainfall in January and March showed a decreasing trend and significant at 0.05 while June at 0.01 level, respectively. Rainfall of February, May and July showed an insignificant decreasing trend. Rainfall during April and September showed an increasing trend, which is significant at 0.05 and 0.01 level respectively while remaining months showed no particular significant trend.

Table.1 Validation of IMD data with CRU data

\begin{tabular}{|l|l|l|l|}
\hline & RMSE & MAPE & $\mathrm{R}^{2}$ \\
\hline Rainfall & 377.2 & 4914 & $0.736 * *$ \\
\hline
\end{tabular}


Table.2 Monthly and seasonal means of rainfall (mm) over Kuttanad region from 1901-2015

\begin{tabular}{|l|c|c|c|c|}
\hline \multicolumn{1}{|c|}{ Month } & \multicolumn{3}{|c|}{ Rainfall (mm) } \\
\hline Jormal & $\begin{array}{c}\text { Standard } \\
\text { deviation }\end{array}$ & CV $(\%)$ & $\begin{array}{c}\text { Percentage contribution to } \\
\text { annual rainfall }\end{array}$ \\
\hline February & 16.3 & 17.0 & 104.5 & 0.6 \\
\hline March & 29.0 & 29.4 & 101.6 & 1.1 \\
\hline April & 53.9 & 40.0 & 74.3 & 2.1 \\
\hline May & 147.5 & 61.8 & 41.9 & 5.7 \\
\hline June & 235.0 & 125.6 & 53.5 & 9.1 \\
\hline July & 479.3 & 150.5 & 31.4 & 18.5 \\
\hline August & 488.4 & 128.0 & 26.2 & 18.8 \\
\hline September & 323.1 & 116.3 & 36.0 & 9.7 \\
\hline October & 252.3 & 119.3 & 47.3 & 12.4 \\
\hline November & 322.6 & 104.1 & 32.3 & 7.6 \\
\hline December & 196.7 & 93.4 & 47.5 & 1.9 \\
\hline Annual & 49.6 & 40.5 & 81.8 & 100 \\
\hline Summer & 436.3 & 137.2 & 31.4 & 59.5 \\
\hline SWM & 1543.1 & 279.4 & 18.1 & 20.0 \\
\hline PM & 519.3 & 144.6 & 27.9 & 3.7 \\
\hline Winter & 94.9 & 48.6 & 51.2 & \\
\hline
\end{tabular}

Table.3 Mann-Kendall rank statistics of monthly seasonal rainfall over Kuttanad region

\begin{tabular}{|l|l|}
\hline Month & Rainfall(mm) \\
\hline January & $-1.9^{*}$ \\
\hline February & -0.179 \\
\hline March & $-1.825^{*}$ \\
\hline April & $1.687^{*}$ \\
\hline May & -0.164 \\
\hline June & $-3.268^{*}$ \\
\hline July & -0.981 \\
\hline August & -0.445 \\
\hline September & $1.852^{*}$ \\
\hline October & -0.479 \\
\hline November & 0.326 \\
\hline December & -1.158 \\
\hline Annual & -0.575 \\
\hline Summer & 0.164 \\
\hline SWM & -0.764 \\
\hline PM & -0.034 \\
\hline Winter & -1.619 \\
\hline
\end{tabular}

*Significant at 0.05 level, $* *$ significant at 0.01 level. 
Table.4 Monthly and seasonal (tri-decadal) contribution of rainfall (\%) from 1901 to 2015 over Kuttanad region

\begin{tabular}{lcccc}
\hline Month/Season & $1901-1930$ & $1931-1960$ & $1961-1990$ & $1991-2015$ \\
\hline June & 19.6 & 19.0 & 18.7 & 16.4 \\
July & 19.2 & 17.9 & 19.6 & 18.5 \\
August & 12.1 & 12.7 & 12.8 & 12.3 \\
September & 9.5 & 8.2 & 10.6 & 11.0 \\
October & 12.9 & 12.3 & 11.2 & 13.7 \\
November & 7.4 & 8.1 & 6.8 & 8.2 \\
Summer & 15.9 & 18.2 & 16.7 & 16.6 \\
Southwest monsoon & 60.5 & 58.1 & 61.6 & 58.1 \\
Post-monsoon & 20.3 & 20.4 & 17.9 & 22.0 \\
Winter & 4.0 & 3.6 & 3.7 & 3.3 \\
\hline
\end{tabular}

Table.5 Decadal mean (\% departure from normal), frequency of excess and deficit rainfall years over Kuttanad region from 1901 to 2015

\begin{tabular}{|c|c|c|c|c|c|c|c|c|c|c|c|c|}
\hline & \multicolumn{3}{|c|}{ Summer } & \multicolumn{3}{|c|}{ Southwest monsoon } & \multicolumn{3}{|c|}{ Post monsoon } & \multicolumn{3}{|c|}{ Winter } \\
\hline $\begin{array}{l}\frac{0}{\tilde{Z}} \\
\stackrel{0}{0} \\
\stackrel{0}{0}\end{array}$ & 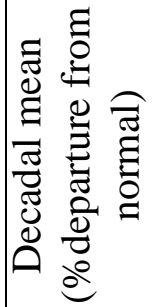 & 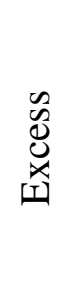 & $\begin{array}{l}\cdot \overline{0} \\
\frac{\pi}{0} \\
0\end{array}$ & 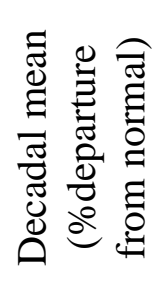 & 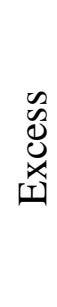 & 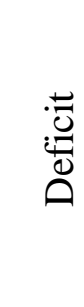 & 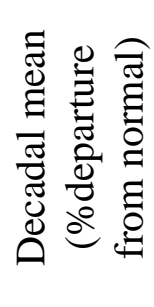 & 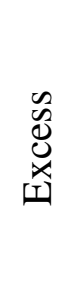 & 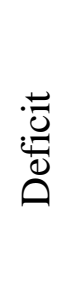 & 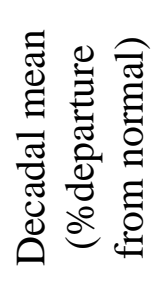 & $\begin{array}{l}\tilde{y} \\
\tilde{d} \\
\stackrel{x}{x} \\
\text { I. }\end{array}$ & 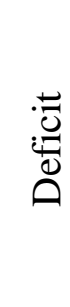 \\
\hline $1901-1910$ & -15.2 & 0 & 2 & -2.0 & 2 & 1 & -7.8 & 1 & 1 & -54.9 & 0 & 2 \\
\hline $1911-1920$ & -6.2 & 0 & 0 & -3.0 & 2 & 2 & 7.6 & 2 & 0 & -22.9 & 2 & 1 \\
\hline $1921-1930$ & 7.8 & 3 & 2 & 2.6 & 2 & 1 & -10.5 & 2 & 3 & 14.4 & 3 & 0 \\
\hline $1931-1940$ & -1.9 & 1 & 1 & -5.8 & 1 & 1 & -7.1 & 2 & 2 & -24.8 & 0 & 0 \\
\hline 1941-1950 & 0.4 & 0 & 1 & 0.7 & 1 & 1 & -8.9 & 2 & 2 & -129.5 & 3 & 1 \\
\hline $1951-1960$ & 23.2 & 3 & 1 & -11.6 & 1 & 2 & -5.0 & 1 & 1 & -62.0 & 2 & 3 \\
\hline $1961-1970$ & -11.7 & 1 & 1 & 2.9 & 4 & 1 & -29.0 & 1 & 4 & -21.0 & 2 & 1 \\
\hline $1971-1980$ & 15.9 & 2 & 2 & -1.8 & 1 & 1 & -6.8 & 1 & 2 & -46.8 & 2 & 2 \\
\hline $1981-1990$ & -8.4 & 1 & 1 & -4.7 & 2 & 1 & -43.7 & 0 & 4 & -66.9 & 2 & 3 \\
\hline $1991-2000$ & -5.9 & 1 & 2 & 0.5 & 2 & 1 & -0.2 & 3 & 3 & -62.6 & 2 & 3 \\
\hline $2001-2010$ & 3.8 & 1 & 0 & -9.3 & 1 & 2 & 9.3 & 3 & 0 & -99.2 & 0 & 4 \\
\hline $2011-2015$ & -3.4 & 1 & 3 & -18.3 & 0 & 1 & -11.3 & 0 & 0 & -6.0 & 1 & 0 \\
\hline
\end{tabular}


Fig.1 Location map of Kuttanad

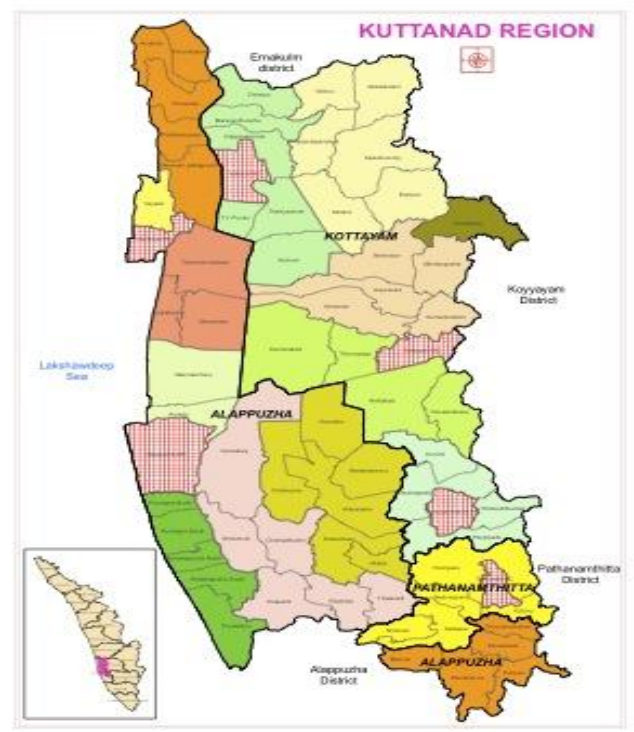

Fig.2 Annual rainfall trends over Kuttanad region from 1901-2015

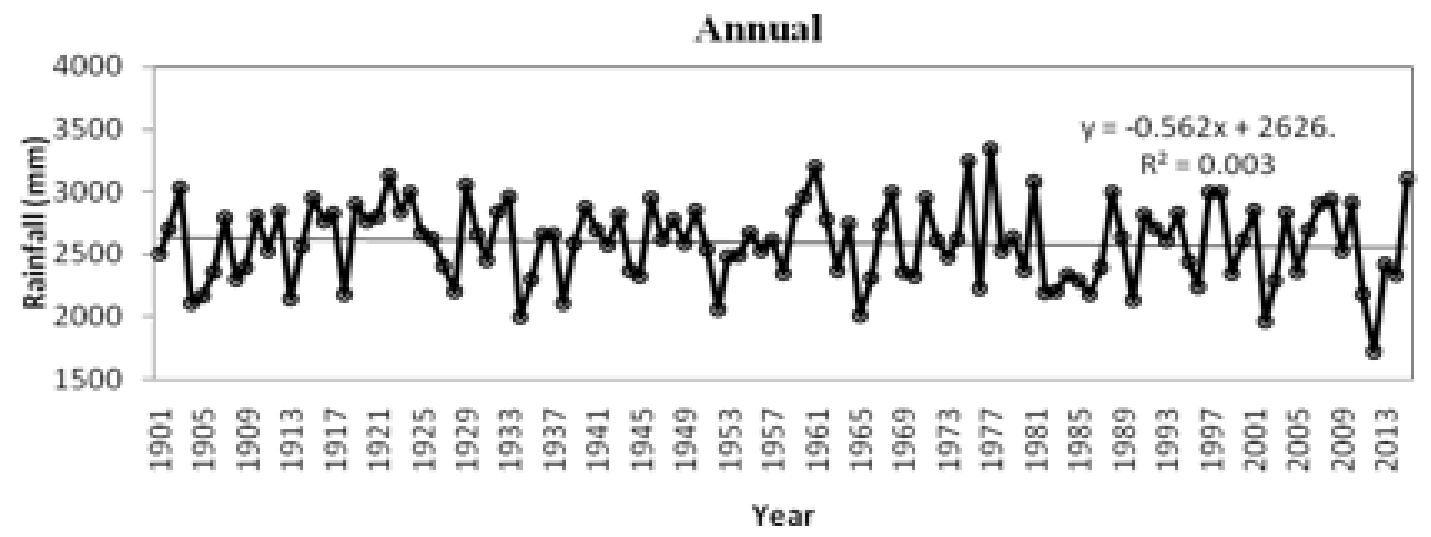

Fig.3 Seasonal rainfall trends over Kuttanad region from 1901-2015

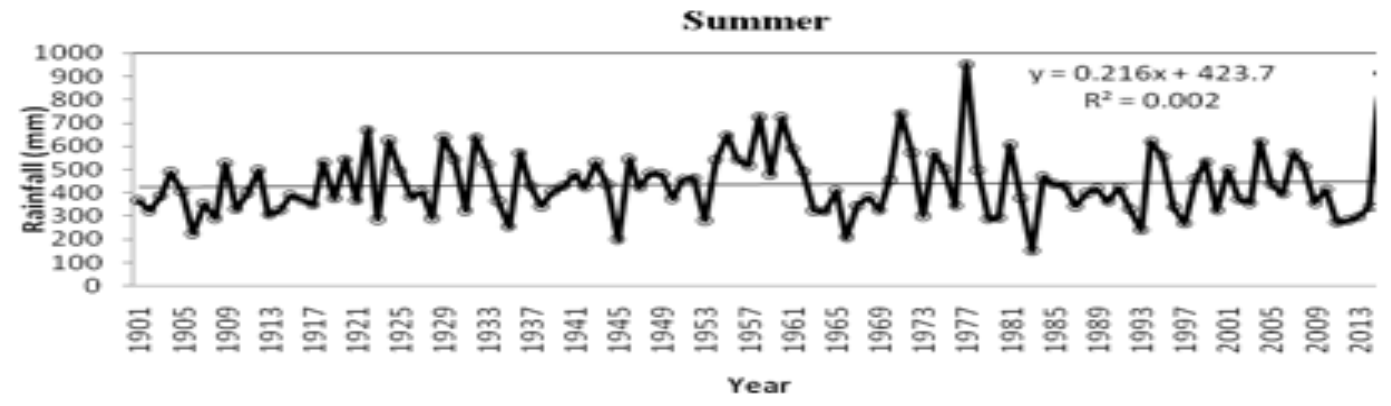




\section{Southwest monsoon}

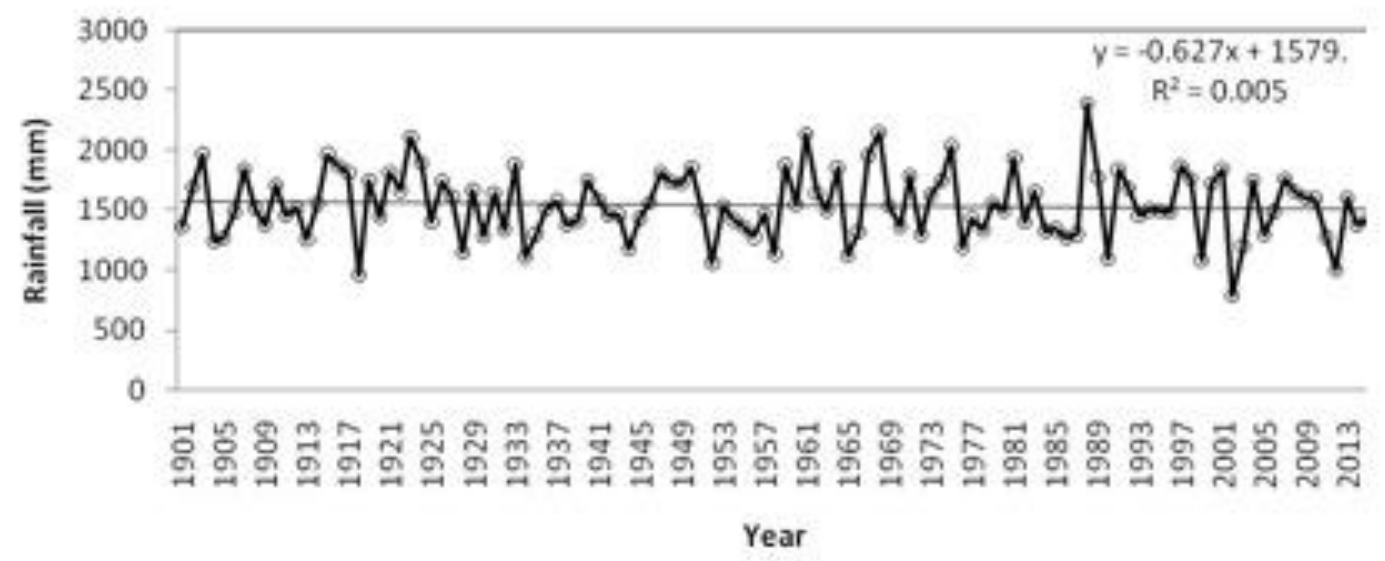

\section{Post monsoon}

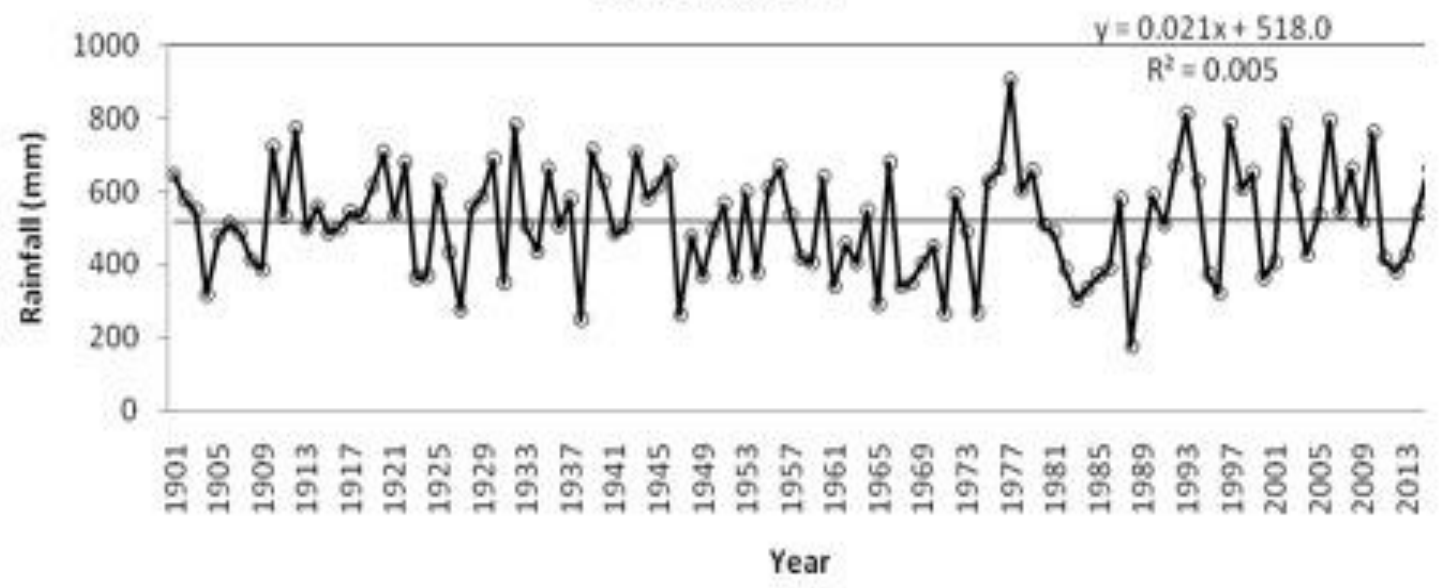

Winter

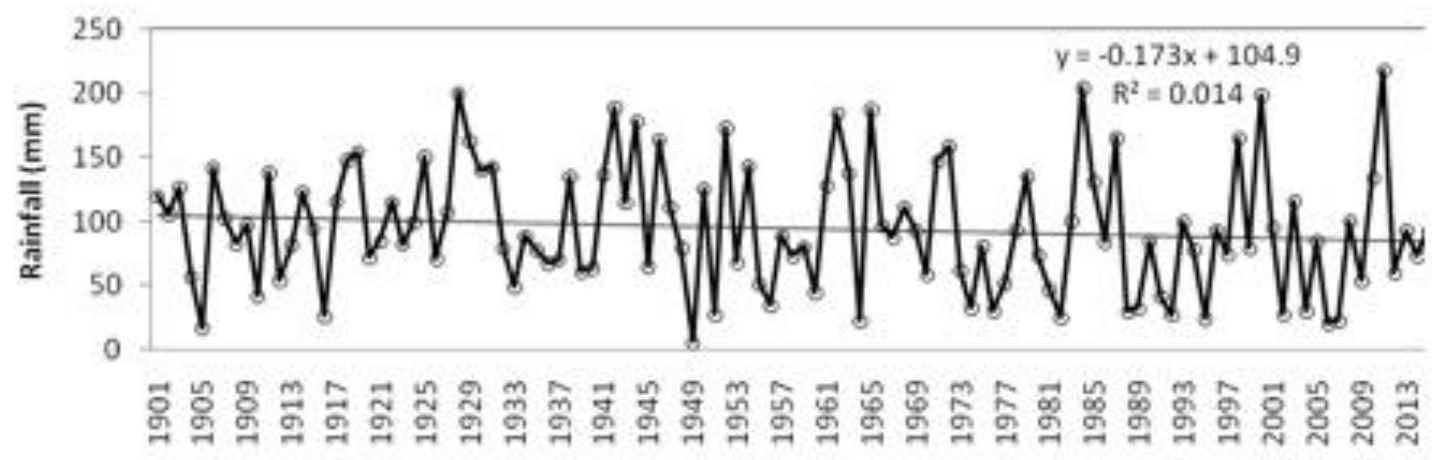

Year 
The study also revealed that, there was a decline in (19.6-16.4\%) rainfall contribution of June to the annual rainfall over a tridecadal period of time from 1901 to 2015 (Table 4). Unlike in June, the contribution of rainfall during July and August were stable. In contrast, the contribution of rainfall during September $(9.5-11 \%)$ is increasing. October and November rainfall also showed similar increasing trends. As a whole, the percentage rainfall contribution during the southwest monsoon (60.5-58.1\%) and winter (4-3.3\%) was declining while increasing during summer (15.9-18.2) and post-monsoon season (20.3-22 \%). However, rainfall during both monsoon seasons was stable while instable in remaining months. Rainfall increase during September, October and November would be beneficial to the winter rice crop which is the major rice season of Kuttanad region. The rainfall during these months is essential for reducing excess salinity and washing out of the toxic chemicals accumulated in the soil. Because of this, the soils of this region are popularly known as problem soils.

\section{Shifts in decade-wise annual and seasonal rainfall}

Decadal Percentage departure of annual and seasonal rainfall, frequencies of excess and deficit years are depicted in Table 5. The deficient or excess rainfall years are defined for those years when rainfall is less or more than the standard deviation. During the wet decade (southwest monsoon) 1901-1910, there were two excess rainfall years and during the period of 1911-1930, four excess years and three deficit years were observed. During the next five (1931-1980) decades of the wet period, eight excess years and six deficit years had been found. In the southwest monsoon period of 1981-2015, there were five deficit years and five excess years. During the period of 1901-2015, the number of deficit years was more (20) than the number of excess years (19) on annual basis while excess rainfall years less than deficit rainfall years during summer, post-monsoon and winter seasons.

The significant decline in rainfall during the start of Kharif crop, June is major concern of this region. The increased rainfall during April is benefit to the plantation crops and lowland spices. The rainfall increase during September, prior to the winter crop is benefit to the rabi rice which is the major rice growing season of this region. The decreasing trend in southwest monsoon rainfall over Kerala is supported by other researchers (Rupa Kumar et al., 1992; Guhathakurta and Rajeevan, 2007, Krishnakumar, 2009).

\section{References}

Battisti, D. S., and Naylor, R. L. 2009. Historical warnings of future food insecurity with unprecedented seasonal heat. Science, 323: 240-244

Brown, M. E. and Funk, C. C. 2008. Food security under climate change. Science 319, 580-581.

Gourdji, S.M., Sibley, A.M., Lobell, D.B. 2013. Global crop exposure to critical high temperatures in the reproductive period: historical trends and future projections. Environ. Res. Lett. 8, 024041.http://dx.doi.org/10.1088/17489326/8/2/ 024041

Guhathakurta, P., Rajeevan, M., 2007. Trends in the rainfall pattern over India. International Journal of Climatology, 28(11): 1453-1469.

Knox, J., T. Hess, A. Daccache \& T. Wheeler. 2012. Climate change impacts on crop productivity in Africa and South Asia. Environmental Research Letters, 7(3): 034032.

Krishnakumar, K.N, Rao, G.S.L.H.V.P. Gopakumar, C.S. 2009. Rainfall trends in twentieth century over Kerala, India, 
Atmospheric Environment 43 (2009) 1940-1944.

Lobell, D.B., Burke, M.B., 2008. Why are agricultural impacts of climate change so uncertain? The importance of temperature relative to precipitation. Environ. Res. Lett. 3, 8

Mooley, D.A., Parthasarathy, B., 1983. Variability of Indian summer monsoon rainfall and tropical circulation features. Monthly Weather Review 111, 967-968

Parthasarathy, B (1984). Some aspects of large-scale fluctuations in the summer monsoon rainfall over India during 1871-1978 Ph.D. thesis, Poona University,

Parthasarathy, B., Dhar, O.N., 1978. Climate Fluctuations Over Indian Region Rainfall: a Review, vol. 31. Indian Institute of Tropical Meteorology, Pune. Research Report No. RR-025.

Parthasarathy, B., Rupakumar, K., Munot,
A.A., 1993. Homogeneous Indian monsoonrainfall: variability and prediction. In: Proceedings of the Indian Academy of Sciences (Earth Planetary Sciences), vol. 102, pp. 121-155.

Pramanik, S.K., Jagannathan, P., 1954. Climate change in India - 1: rainfall. Indian Journal of Meteorology Geophysics 4, 291-309.

Rupa Kumar, K., Pant, G.B., Parthasarathy, B., Sontakke, N.A. 1992. Spatial and subseasonal patterns of the long term trends of Indian summer monsoon rainfall. International Journal of Climatology 12, 257-268

Singh, N., Sontakke, N. A., Singh, H. N. and Pandey, 2005. A. K., Recent trend in spatiotemporal variation of rainfall over Indian investigation into basin-scale rainfall fluctuations. IAHS Publication No. 296, pp. 273-282.

\section{How to cite this article:}

Shajeesh Jan, P., S. Paneerselvam, V. Geethalakshmi, K.P. Ragunath, Ga. Dheebakaran and Jagannathan, R. 2017. Centurial Rainfall Variability in Below Sea Level Farming Region of Kerala, India. Int.J.Curr.Microbiol.App.Sci. 6(12): 2414-2422. doi: https://doi.org/10.20546/ijcmas.2017.612.279 